\title{
Investigation of reasonable sections for simply supported steel plate- concrete composite girder bridge
}

\author{
J.W. ZHU ${ }^{1,2} \& H . L^{1} U^{1} \& X L Z H A I^{2}$ \\ 1. Key Laboratory for Bridge and Tunnel Engineering of Shaanxi Province, Chang'an University , \\ Xi'an , Shaanxi , China \\ 2. CCCC First Highway Consultants Co Ltd, Xi'an, Shaanxi, China
}

KEYWORD: Steel plate-concrete composite girder bridge; Economical height of girder; Live load composite girder; Reasonable section structures.

ABSTRACT: The simply supported steel plate-concrete composite girder bridge is widely used in bridge construction. Based on the economical height of girders formulas introduced in this paper, the structure parameters, including the height, stiffness of girders, the minimum compressive flange area, the ratio of steel consumption to span and the stress of the concrete slab are analyzed to obtain the reasonable section structures for this type of bridge. This is under the typical bridge width and the proper main girders arrangement in the state of stress control. The design suggestion of the corresponding structural parameters is given to guide the practical engineering.

\section{INTRODUCTION}

The simply supported steel plate-concrete composite girder bridge has the characteristics of simplified structure, high strength, light weight, effective factory production, fast construction speed, which is widely used in bridge construction. As one of the most basic form of bridge structure, a wealth of research results, engineering experiences and application examples abroad can be given a reference to design the simply supported steel plate-concrete composite girder bridge for china. However, because of significant differences between china and other nations such as unit system, bridge load level and standard design method, which cause some inevitable particularity of designing the composite girder bridge in china. The practical experiences and design scheme from foreign countries cannot be copied completely. According to the characteristics of structure and load situations of highway in china, the reasonable sections for the simply supported steel plate-concrete composite girder bridge is investigated in this paper, in order to provide reference for structural design and engineering application (Nie 2005; Wu 2006).

In accordance with load differences of different construction methods in construction stage, the steel plate-concrete composite girder bridge can be divided into two forms: the live load composite girder and the dead load composite girder. The live load composite girder starts to bear load immediately in the steps of steel girder erection and concrete pouring. After finished phase, the stress of the steel girder is superposition of the dead load stress and the live load stress. So, the live load composite girder has a higher stress level, resulting in a greater consumption of steel, whereas the concrete slab that start to bear load only after the combination of the steel girder and the concrete slab has a lower stress. Since it is no need of the support and the temporary pier in construction, and has no significant consequences for clearance under the bridge, the live load composite girder is more widely used in bridge engineering. Considering wider application and more complicated mechanical performance, the live load composite girder is taken as the object of the research to conduct the reasonable sections analysis in this paper.

\section{GIRDERS ARRANGEMENT}

Determining the numbers and the spacing of girders is most important work for the cross section structure design, which is a main factor to affect the economic performance. The girder spacing is smaller, and the economical performance is poorer. When the girder spacing is too large, a dense di- 
aphragm must be provided for the structure to reduce the span of the bridge decks. The stress state of the main girders as well as the bridge deck should be considered in a reasonable arrangement for cross section design.

Table 1. Main girder arrangement in typical width of bridges

\begin{tabular}{ccc}
\hline $\begin{array}{c}\text { Design } \\
\text { lanes }\end{array}$ & $\begin{array}{c}\text { Width/ } \\
\mathrm{m}\end{array}$ & $\begin{array}{c}\text { Main girders arrange- } \\
\text { ment } / \mathrm{m}\end{array}$ \\
\hline & & $2 \times 3.5+2 \times 1.0=9.0$ \\
$2 \times 3.0+2 \times 1.5=9.0$ \\
$3 \times 2.5+2 \times 0.75=9.0$ \\
$3 \times 2.0+2 \times 1.25=9.0$ \\
& 9 & $11 \times 3.5+2 \times 1.5=41.5$ \\
& & $13 \times 3.0+2 \times 1.25=41.5$ \\
& & $20 \times 2.5+2 \times 0.75=41.5$ \\
8 & 41.5 & $2 \times 0.75=41.5$ \\
& &
\end{tabular}

Typical main girder arrangement for 2-lane and 8-lane in the typical width of bridges from JTG B01-2014 (Technology standard of highway engineering 2014) are shown in Table 1. By adjusting the cantilever length of the external girder to ensure that the spacing of main girders is $2,2.5,3$, $3.5 \mathrm{~m}$. In the actual structure design, the reasonable size of cantilever length of the girder outside should be guaranteed by the numbers and the spacing of girders.

\section{ECONOMIC HEIGHT OF GIRDERS}

\section{Assumption of calculated loads}

For convenience, the two basic load combinations, the dead load and the live load, were taken accounted here, without regard for the influence of temperature, temperature gradient and support settlement. The designed cross section of steel plate-concrete composite beam is shown in Figure 1. Assuming thickness of the bituminous concrete pavement layer is $10 \mathrm{~cm}$. According to literature (Wu 2004), the depth of concrete slab, $d(\mathrm{~cm})$ can be expressed as:

$$
d=K_{1}(3 b+11)
$$

where $b=$ girder spacing $(\mathrm{m}) ; k_{l}=$ coefficient related to loads, and $k_{1}=1.0 \sim 1.2$ normally, choose larger value when axle weight is larger. based on the traffic load conditions, assume $k_{l}=1.2$ in this calculation.

Due to literature (Wu 2004), the steel self-weight per unit area, $w\left(k N / \mathrm{m}^{2}\right)$ can be expressed as:

$$
w=2.0+0.05(L-30)
$$

where $L=$ calculation length of main girder $(\mathrm{m})$. 


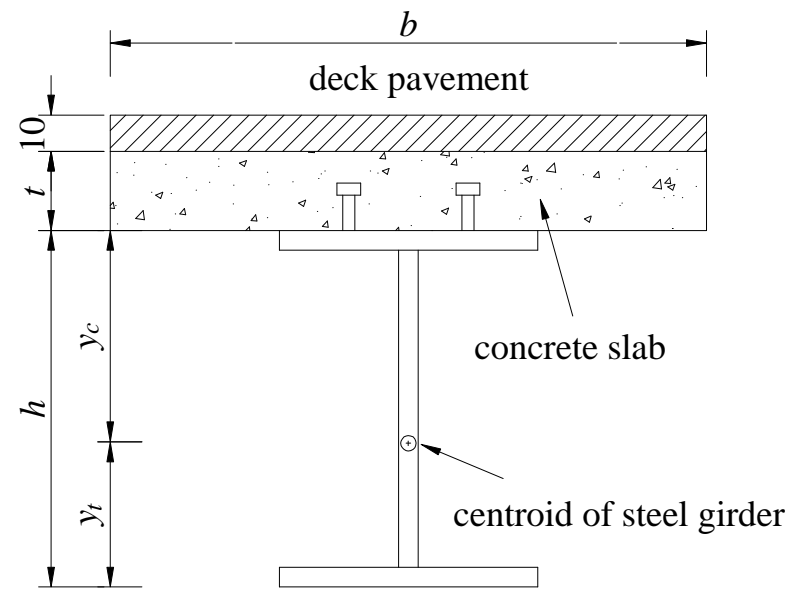

Figure 1. Cross section of steel plate-concrete composite girder

Although the live load transverse distribution coefficient is related to the stiffness of girder and cross beam, bridge calculation width, calculation span length, the grid stiffness is usually larger than 20 , and the live load can be distributed properly. Thus, to simplify the calculation, load transverse distribution non-uniform coefficient selects 1.15.

\section{Calculation for econimic height of girders}

Under the effect of the dead load in the first stage, only steel girder section take effect. while the secondary load and live load will be afforded by composite section combined with steel girder and reinforcement concrete plate. Assuming the steel plate girder is designed according to stress, the largest allowable tensile stress is $\sigma_{t a}$, and the largest allowable compressive stress is $\sigma_{c a}$. When only steel girder affords loads, the section modules of upper flange section and lower flange section are $W_{c}$ and $W_{t}$ respectively. However, as composite steel girder start to bear load, the section modules of upper flange section and lower flange section are $W_{o c}$ and $W_{o t}$ respectively. The bending moments under first stage dead load, secondary load and travelling load are $M_{d 1}, M_{d 2}$, and $M_{1}$ respectively. Then the composite girder stresses of upper flange $\sigma_{c}$, lower flange $\sigma_{t}$ can be obtained:

$$
\begin{gathered}
\sigma_{c}=\frac{M_{d 1}}{W_{c}}+\frac{M_{d 2}+M_{1}}{W_{o c}}=\left(1+\beta \alpha_{c}\right) \frac{M_{d 1}}{W_{c}} \\
\sigma_{t}=\frac{M_{d 1}}{W_{t}}+\frac{M_{d 2}+M_{1}}{W_{o t}}=\left(1+\beta \alpha_{t}\right) \frac{M_{d 1}}{W_{t}}
\end{gathered}
$$

where $\alpha_{c}=W_{c} / W_{o c} ; \alpha_{t}=W_{t} / W_{o t} ; \beta=\left(M_{d 2}+M_{1}\right) / M_{d 1}$;

As the formulas (3) (4):

$$
\frac{M_{d 1}}{W_{c}}=\frac{\sigma_{c}}{1+\beta \alpha_{c}} ; \quad \frac{M_{d 1}}{W_{t}}=\frac{\sigma_{t}}{1+\beta \alpha_{t}} ;
$$

Let $\sigma_{v}=\sigma_{c} /\left(1+\beta / \alpha_{c}\right) ; \sigma_{w}=\sigma_{t} /\left(1+\beta / \alpha_{t}\right)$, then the economic girder height of live load composite girders:

$$
h=\left(\frac{6 h / t}{\sigma_{v}+\sigma_{w}} M_{d 1}\right)^{1 / 3}
$$

In the formulas (6), $\mathrm{h} / \mathrm{t}$ is the limit value of web depth-thickness ratio according to literature [4]. $\alpha_{c}, \alpha_{t}$ can be obtained as they are related to section sizes, which required multiply iteration to get economic girder height. 


\section{DETAILS OF SECTIONS ANALYSIS}

\section{Height of main girders}

The relationship between the height of steel girders(h) and the span(L) in the highway level-I load is shown in Figure 2. the main girder spacing changes from 2.0, 2.5, 3.0 to 3.5m with the width of 9m and $41.5 \mathrm{~m}$. The ratio of height to thickness of web is supposed to 200., and the minimum web thickness is $8 \mathrm{~mm}$. The steel girder is made form Q345 with maximum design tensile stress of steel $265 \mathrm{MPa}$ and the maximum design compressive stress of steel $225 \mathrm{MPa}$, according to JTG D642015 (Specifications for design of highway steel bridge 2015). In the reasonable span 20m of steel plate girder bridge, the live load composite girder bridges' economic steel height is 1/14 1/26 of the span. Girder spacing have larger influence on steel height. Steel girder height increases as girder spacing increases under different spans.

It must be noted that the height of steel girder derived in this paper is based on the principal of equal amount of steel. But normally in the actual structural design, the derived economic height of steel girder is the superior limits for the simple supported steel plate-concrete composite girder. If the clearance of bridges does not satisfy the design code, the height of girder can be lower and the thickness of flange can be increased to arrive at the stress design requirements

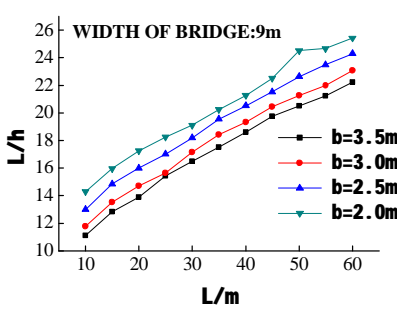

(a) width : $9 \mathrm{~m}$

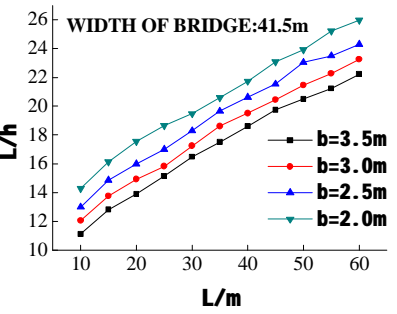

(b) width: $41.5 \mathrm{~m}$

Figure 2 The relationship between the height of steel girder (h) and the span(L)

\section{Stiffness of main girders}

It should not only satisfy the stress-controlled conditions, but in fact also must meet the requirements of structure stiffness-controlled condition for structure design in structural design process. According to JTG D64-2015 (Specifications for design of highway steel bridge 2015), the deflection $\delta$ of the simply supported steel girder bridge caused by live load shall not be greater than 1/600. Based on the stress-controlled design principle, the curve of deflection caused by live load changes with span is shown in figure 3 . Under the stress-controlled design conditions, we can see from the figure that the greater the girder spacing, the needed stiffness is greater when the structure stressed and the corresponding deflection is smaller. Different bridge width have smaller influence on the deflection of main girder. When the bridge width is smaller, the cantilever length of deck has large influence on the structure. So the reasonable cantilever length of bridge deck has important influence on the size of the dimension. the deflection of the live load composite steel plate girder caused by live load is 1/1500 1/4400 under stress-controlled design conditions in figure 3, which is still smaller than the deflection allowance by the code. It further shows that the live load composite girder bridge is controlled by stress index at reasonable steel beam height

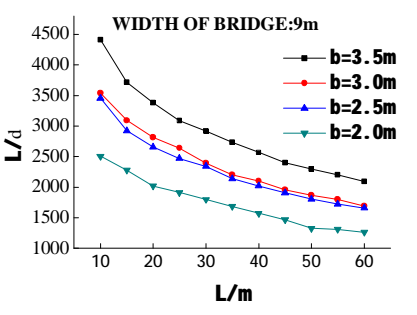

(a) width : $9 \mathrm{~m}$

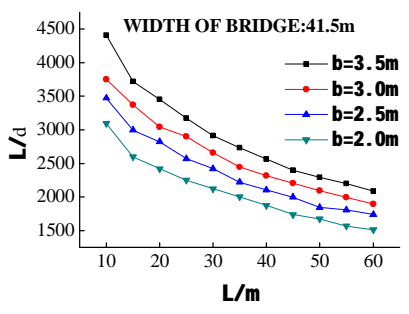

(b) width: $41.5 \mathrm{~m}$

Figure 3 The ratio of span to deflection $(\mathrm{L} / \delta)$ with the varying span $(\mathrm{L})$ 


\section{Minimum compressive flange area}

A great deal of scientific research shows that the performance of the steel materials is affected by the rolling conditions. With the increasing of thickness of the steel plate, the strength of the steel plate will reduce gradually, and the problems of welding steel plate and the thick plate effect will gradually come out. Therefore, the thickness of the steel plate should not be more than $60 \mathrm{~mm}$. JTG D64-2015 (Specifications for design of highway steel bridge 2015) defines the limit ratio of the width to height for the compressive flange of bending-compression members. For that the area of compressive flange should not be more than $36000 \mathrm{~mm}^{2}$. The minimum required area of compressive flange $A_{\mathrm{fc}}$ shows in the figure 4 for composite girder under stress-controlled limit. We can see from this two figures that the thickness of compressive flange calculated by the formulas of economic height of girder increases significantly when the span of bridge is beyond $45 \mathrm{~m}$. So, sit is advised that the span of the live load composite girder should better not greater than $45 \mathrm{~m}$ to avoid effectively the thick plate effort. When the span of structure is greater than $60 \mathrm{~m}$, it is a reasonable section selection with the use of the box-shape girders

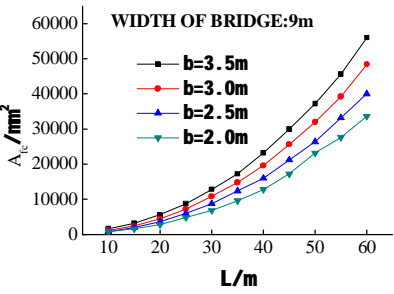

(a) width : $9 \mathrm{~m}$

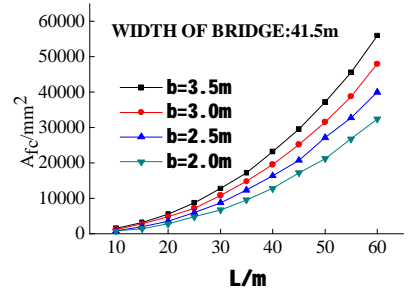

(b) width: $41.5 \mathrm{~m}$

Figure 4 The minimum required area of compressive flange $A_{f c}$ with the varying span (L)

\section{Consumption amount of steel}

Figure 5 shows the change of the consumption amount of steel $(\mathrm{P})$ per unit bridge width vary with the span (L) under the economic height of the live load composite bridge. It can be known that he main beam steel consumption is smaller per unit width because of the proportion of live load is smaller as the span is smaller. When the span changes from $20 \mathrm{~m}$ to $60 \mathrm{~m}$, the steel consumption of the live load composite girder per unit bridge width will increase from $450 \sim 500 \mathrm{~mm} / \mathrm{m}$ to 800 $900 \mathrm{~mm}^{2} / \mathrm{m}$. With the increasing of bridge span, steel consumption of the unit bridge width will increase gradually. However, when the bridge width and the girder spacing is bigger, the steel consumption is smaller. It is advised that a greater girder spacing can be used in the live load steel plate-concrete composite girder. Meanwhile, because structures also must satisfy the stress and stiffness limits, and considering the shear lag effect and thick plate effect, the girder spacing cannot select the lager spacing. It should better use the spacing of $3.0 \sim 3.5 \mathrm{~m}$ as the bridge width is bigger. Since the cantilever length of the girder outside has a bigger influence on the amount of steel, It should better consider priority the reasonable cantilever layout of girders, and select the most reasonable sectional index integrating the girder spacing as the bridge width is smaller.

It also can be seen from the figure 5, when the bridge width is $41.5 \mathrm{~m}$, with the decreasing of the girder spacing, the consumption amount of steel increased gradually, the change of the girder spacing has a decisive influence on the steel plate girder bridge. But when the bridge width is $9 \mathrm{~m}$, with the girder spacing decreasing, the consumption amount of steel don't increase, the change of girder spacing don't have decisive influence on the amount of steel plate consumption. 


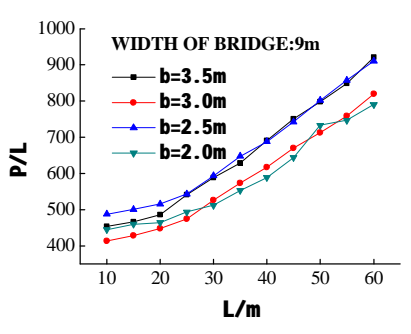

(a) width : $9 \mathrm{~m}$

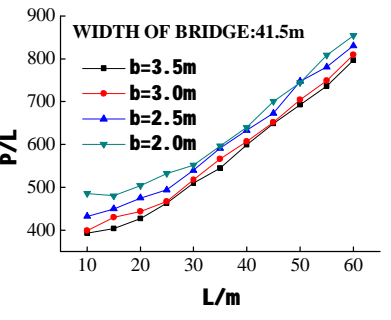

(b) width: $41.5 \mathrm{~m}$

Figure 5 The consumption amount of steel $(\mathrm{P})$ with the varying span $(\mathrm{L})$

\section{Normal stress in the top of concrete deck}

The normal stress in the top of concrete deck $\left(\sigma_{d}\right)$ for the live load composite girder is shown in figure 6. The compressive stress in the top of the concrete deck increased with the increasing of the span, but overall stress level is low, which is just -2 -7 MPa. When the girder spacing is bigger, the stress level is lower. According to JTG D62-2004 (Code for design of highway reinforced concrete and prestressed concrete bridges and culverts 2004), the design compressive stress of C30 is 13.8 $\mathrm{MPa}$. As known from the analysis of the above, the stress level of the live load composite girder is lower. So it is not need to use high strength concrete, even the C30 can meet the stress-controlled design conditions.

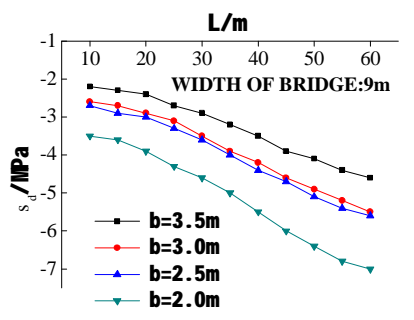

(a) width : $9 \mathrm{~m}$

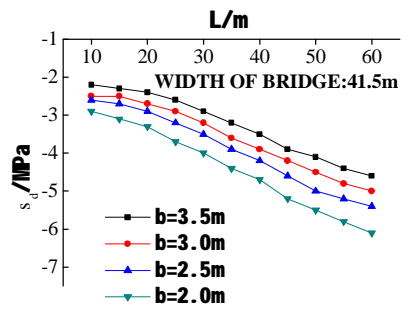

(b) width: $41.5 \mathrm{~m}$

Figure 6 The normal stress in the top of concrete deck $\left(\sigma_{d}\right)$ with the varying span (L)

\section{CONCLUSION}

Based on the research of reasonable sections for the live load steel plate-concrete composite girder in this paper, main conclusions obtained are in the following: (1) For live load composite steel girder, the economic ratio of height to span is $1 / 14 \sim 1 / 26$. (2) The girder spacing has a great influence on the steel girder height. The girder height will increases gradually along with the spacing increasing. (3) Under the stress-controlled situation, the larger the girder spacing is, the larger the required girder stiffness is when affording loads, and the smaller the deformation is accordingly. The width has a small influence on the girder deformation. (4) When the span length of live load composite girder is larger than $45 \mathrm{~m}$, the height of steel girder can be increased properly to satisfy mechanical requirements, and thus can avoid the plate thickness effect. When the span is larger than $60 \mathrm{~m}$, box-shape girders can guarantee mechanical reasonable girder section. (5) The compressive stress of live load composite girder is so small that concrete C30 could satisfy stress control requirements.

\section{REFERENCES}

[1] National Standards of the People's Republic of China. (JTG D62-2004). (2004). Code for design of highway reinforced concrete and prestressed concrete bridges and culverts.

[2] National Standards of the People's Republic of China. (JTG B01-2014). (2014). Technology standard of highway engineering 
[3] National Standards of the People's Republic of China. (JTG D64-2015). (2015). Specifications for design of highway steel bridge.

[4] Nie, J.G. (2005). Test, thorey and application for the structure of steel and concrete composite beams. Beijing: Science Press.

[5] Wu, C. 2004. Research of reasonable girders sections of simply-supported steel plate girder highway bridges in china. Bridge Construction (6):35-38.

[6] Wu C. (2006). Modern steel bridge. Beijing: China Commuciations Press. 